\title{
MD INTERVIEW
}

\section{AN INTERVIEW WITH PAUL A. SAMUELSON}

\author{
Interviewed by William A. Barnett \\ University of Kansas
}

December 23, 2003

It is customary for the Interviewer to begin with an introduction describing the circumstances of the interview and providing an overview of the nature and importance of the work of the interviewee. However, in this case, as Editor of this journal, I feel it would be presumptuous of me to provide my own overview and evaluation of the work of this great man, Paul Samuelson. The scope of his contributions has been so vast (averaging almost one technical paper per month for over 50 years) that it could be particularly difficult to identify those areas of modern economic theory to which he has not made seminal contributions. ${ }^{1}$ In addition to his over 550 published papers, his books are legendary. He once said: "Let those who will—write the nation's laws—if I can write its textbooks."

Instead of attempting to provide my own overview, I am limiting this introduction to the following direct (slightly edited) quotation of a few paragraphs from the Web site, The History of Economic Thought, which is maintained online by the New School University in New York ${ }^{2}$ :

Perhaps more than anyone else, Paul A. Samuelson has personified mainstream economics in the second half of the twentieth century. The writer of the most successful principles textbook ever (1948), Paul Samuelson has been not unjustly considered the incarnation of the economics "establishment" - and as a result, has been both lauded and vilified for virtually everything right and wrong about it.

Samuelson's most famous piece of work, Foundations of Economic Analysis (1947), is one of the grandest tomes that helped revive Neoclassical economics and launched the era of the mathematization of economics. Samuelson was one of the progenitors of the Paretian revival in microeconomics and the Neo-Keynesian Synthesis in macroeconomics during the post-war period.

The wunderkind of the Harvard generation of 1930s, where he studied under Schumpeter and Leontief, Samuelson had a prodigious grasp of economic theory, which has since become legendary. An unconfirmed anecdote has it that at the end of Samuelson's dissertation 


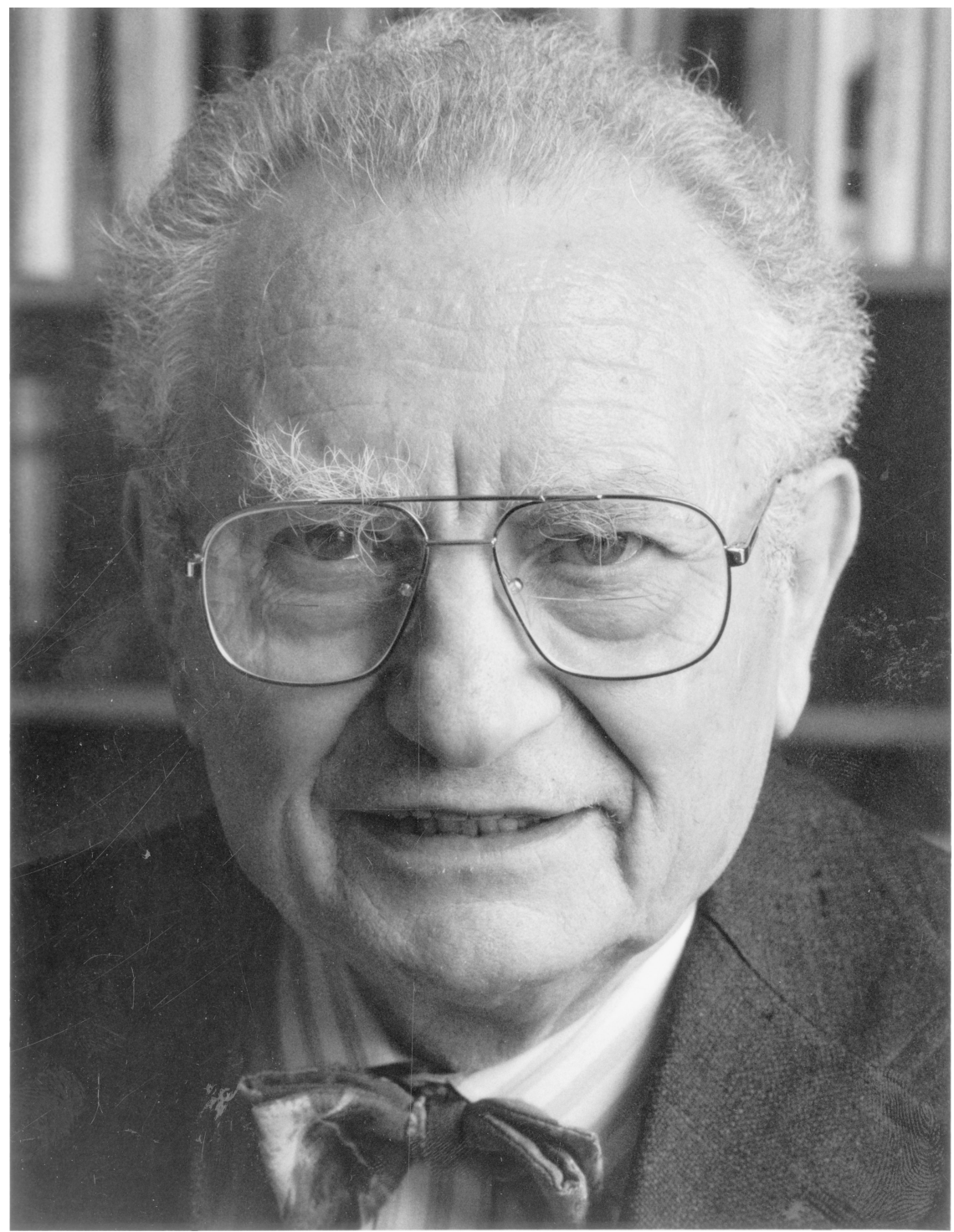

Figure 1. Paul A. Samuelson.

defense, Schumpeter turned to Leontief and asked, "Well, Wassily, have we passed?" Paul Samuelson moved on to M.I.T. where he built one of the century's most powerful economics departments around himself. He was soon joined by R.M. Solow, who was to become Samuelson's sometime co-writer and partner-in-crime.

Samuelson's specific contributions to economics have been far too many to be listed herebeing among the most prolific writers in economics. Samuelson's signature method of 
economic theory, illustrated in his Foundations (1947), seems to follow two rules which can also be said to characterize much of Neoclassical economics since then: With every economic problem, (1) reduce the number of variables and keep only a minimum set of simple economic relations; and (2) if possible, rewrite it as a constrained optimization problem.

In microeconomics, he is responsible for the theory of revealed preference (1938, 1947). This and his related efforts on the question of utility measurement and integrability (1937, 1950) opened the way for future developments by Debreu, Georgescu-Roegen, and Uzawa. He also introduced the use of comparative statics and dynamics through his "correspondence principle" (1947), which was applied fruitfully in his contributions to the dynamic stability of general equilibrium $(1941,1944)$. He also developed what are now called "Bergson-Samuelson social welfare functions" (1947, 1950, 1956); and, no less famously, Samuelson is responsible for the harnessing of "public goods" into Neoclassical theory $(1954,1955,1958)$.

Samuelson was also instrumental in establishing the modern theory of production. His Foundations (1947) are responsible for the envelope theorem and the full characterization of the cost function. He made important contributions to the theory of technical progress (1972). His work on the theory of capital is well known, if contentious. He demonstrated one of the first remarkable "Non-Substitution" theorems (1951) and, in his famous paper with Solow (1953), initiated the analysis of dynamic Leontief systems. This work was reiterated in his famous 1958 volume on linear programming with Robert Dorfman and Robert Solow, wherein we also find a clear introduction to the "turnpike" conjecture of linear von Neumann systems. Samuelson was also Joan Robinson's main adversary in the Cambridge Capital Controversy-introducing the "surrogate" production function (1962), and then subsequently (and graciously) relenting (1966).

In international trade theory, he is responsible for the Stolper-Samuelson Theorem and, independently of Lerner, the Factor Price Equalization theorem (1948, 1949, 1953), as well as (finally) resolving the age-old "transfer problem" relating terms of trade and capital flows, as well as the Marxian transformation problem (1971), and other issues in Classical economics $(1957,1978)$.

In macroeconomics, Samuelson's multiplier-accelerator macrodynamic model (1939) is justly famous, as is the Solow-Samuelson presentation of the Phillips Curve (1960) to the world. He is also famous for popularizing, along with Allais, the "overlapping generations" model which has since found many applications in macroeconomics and monetary theory. In many ways, his work on speculative prices (1965) effectively anticipates the efficient markets hypothesis in finance theory. His work on diversification (1967) and the "lifetime portfolio" (1969) is also well known.

Paul Samuelson's many contributions to Neoclassical economic theory were recognized with a Nobel Memorial prize in 1970.

Keywords: Microeconomics, Macroeconomics, Trade, Welfare Economics, Finance Theory, Capital Theory, Revealed Preference, Overlapping Generations

Barnett: As an overture to this interview, can you give us a telescopic summary of 1929 to 2003 trends in macroeconomics?

Samuelson: Yes, but with the understanding that my sweeping simplifications do need, and can be given, documentation. 
As the 1920's came to an end, the term macroeconomics had no need to be invented. In America, as in Europe, money and banking books preached levels and trends in price levels in terms of the Fisher-Marshall $M V=P Q$. Additionally, particularly in America, business-cycles courses eclectically nominated causes for fluctuations that were as diverse as "sunspots," "psychological confidence," "over- and underinvestment" pathologies, and so forth. In college on the Chicago Midway and before 1935 at Harvard, I was drilled in the Wesley Mitchell statistical descriptions and in Gottfried Haberler's pre-General Theory review of the troops. Read the puerile Harvard book on The Economics of the Recovery Program, written by such stars as Schumpeter, Leontief, and Chamberlin, and you will agree with a reviewer's headline: Harvard's first team strikes out.

Keynes's 1936 General Theory-paralleled by such precursors as Kahn, Kalecki, and J.M. Clark-gradually filled in the vacuum. Also, pillars of the $M V=P Q$ paradigm, such as all of Fisher, Wicksell, and Pigou, died better macroeconomists than they had earlier been-this for varied reasons of economic history.

Wicksell was nonplussed in the early 1920's when postwar unemployment arose from his nominated policy of returning after 1920 back to pre-1914 currency parities. His long tolerance for Say's law and neutrality of money (even during the 1865-1900 deflation) eroded away in his last years. For Fisher, his personal financial losses in the 1929-1934 Depression modified his beliefs that $V$ and $Q / V$ were quasi constants in the $M V=P Q$ tautology. Debt deflation all around him belied that. Pigou, after a hostile 1936 review of The General Theory (occasioned much by Keynes's flippancies about Marshall and "the classics"), handsomely acknowledged wisdoms in The General Theory's approaches in his 1950 Keynes's General Theory: A Retrospective View.

I belabor this ancient history because what those gods were modifying was much that Milton Friedman was renominating about money around 1950 in encyclopedia articles and empirical history. It is paradoxical that a keen intellect jumped on that old bandwagon just when technical changes in money and money substitutesliquid markets connected by wire and telephonic liquid "safe money market funds," which paid interest rates on fixed-price liquid balances that varied between $15 \%$ per annum and $1 \%$, depending on price level trends-were realistically replacing the scalar $M$ by a vector of $\left(M_{0}, M_{1}, M_{2}, \ldots, M_{17}\right.$, a myriad of bonds with tight bid-asked prices, ... ). We all pity warm-hearted scholars who get stuck on the wrong paths of socialistic hope. That same kind of regrettable choice characterizes anyone who bets doggedly on ESP, or creationism, or .... The pity of it increases for one who adopts a simple theory of positivism that exonerates a nominated theory, even if its premises are unrealistic, so long only as it seems to describe with approximate accuracy some facts. Particularly vulnerable is a scholar who tries to test competing theories by submitting them to simplistic linear regressions with no sophisticated calculations of Granger causality, cointegration, colinearities and ill-conditioning, or a dozen other safeguard econometric methodologies. To give one specific example, when Christopher Sims introduces both $M$ and an 


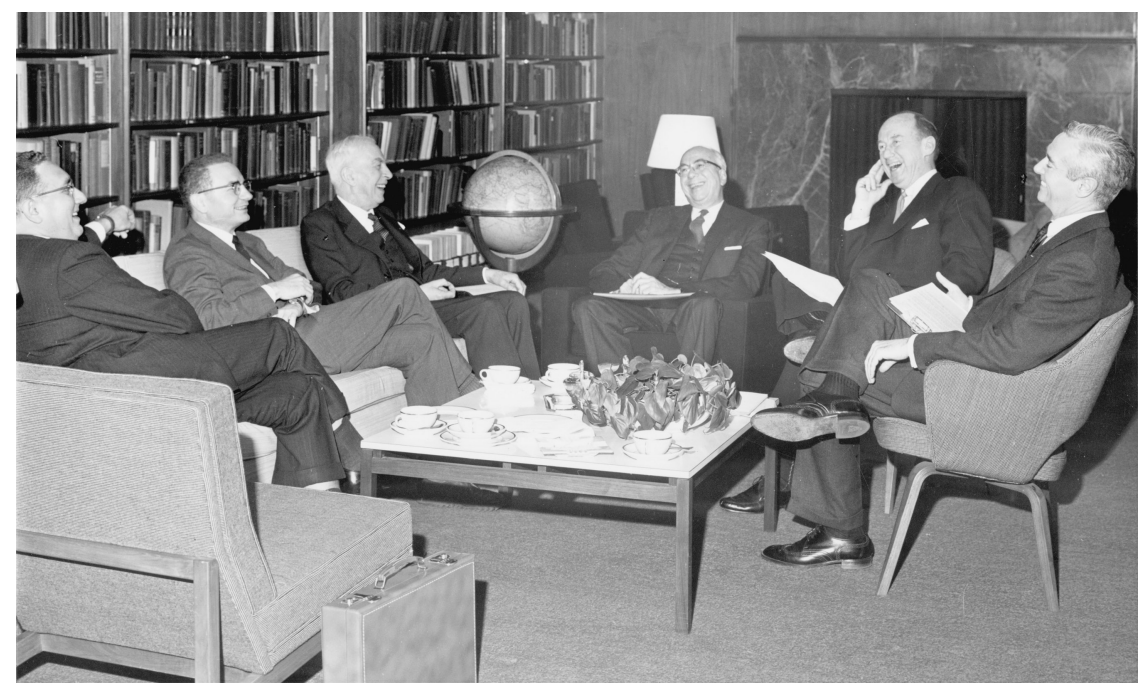

FIGURE 2. New York, February 19, 1961. Seated left to right, participating guests who appeared on the first of The Great Challenge symposia of 1961: Professor Henry A. Kissinger, Director of the Harvard International Seminar; Dr. Paul A. Samuelson, Professor of Economics at MIT and President of the American Economic Association; Professor Arnold J. Toynbee, world historian; Admiral Lewis L. Strauss, former Chairman of the Atomic Energy Commission and former Secretary of Commerce; Adlai E. Stevenson, U.S. Ambassador to the United Nations; and Howard K. Smith, CBS news correspondent in Washington, moderator of the program. The topic: "The World Strategy of the United States as a Great Power."

interest rate in a multiple regression testing whether $M$ drives $P, Q / V$, or $Q$ in some systematic manner congenial to making a constant rate of growth of money supply, $M_{1}$, an optimal guide for policy, then in varied samples the interest rate alone works better without $M$ than $M$ works alone or without the interest rate.

The proof of the pudding is in the eating. There was a widespread myth of the 1970's, a myth along Tom Kuhn's (1962) Structure of Scientific Revolutions lines. The Keynesianism, which worked so well in Camelot and brought forth a long epoch of price-level stability with good $Q$ growth and nearly full employment, gave way to a new and quite different macro view after 1966. A new paradigm, monistic monetarism, so the tale narrates, gave a better fit. And therefore King Keynes lost self-esteem and public esteem. The King is dead. Long live King Milton!

Contemplate the true facts. Examine 10 prominent best forecasting models 1950-1980: Wharton, Townsend-Greenspan, Michigan Model, St. Louis Reserve Bank, Citibank Economic Department under Walter Wriston's choice of Lief Olson, etc. When a specialist in the Federal Reserve system graded models in terms 
of their accuracy for out-of-sample future performance for a whole vector of target macro variables, never did post-1950 monetarism score well! For a few quarters in the early 1970's, Shirley Almon distributed lags, involving $\left[M_{i}(-1), M_{i}(-2), \ldots\right.$, $\left.M_{i}(-n)\right]$, wandered into some temporary alignment with reality. But then, outfits like that at Citibank, even when they added on Ptolemaic epicycle to epicycle, generated monetarism forecasts that diverged systematically from reality. Data mining by dropping the $M_{i}$ 's that worked worst still did not attain statistical significance. Overnight, Citibank wiped out its economist section as superfluous. Meantime, inside the Fed, the ancient Federal Reserve Board-MIT-Penn model of Modigliani, Ando, et al. kept being tweaked at the Bank of Italy and at home. For it, $M$ did matter as for almost everyone. But never did $M$ alone matter systemically, as post-1950 Friedman monetarism professed.

It was the 1970s' supply shocks (OPEC oil, worldwide crop failures, ... ) that worsened forecasts and generated stagflation incurable by either fiscal or central bank policies. That's what undermined Camelot cockiness-not better monetarism that gave better policy forecasts. No Tom Kuhn case study here at all.

Barnett: Let's get back to your own post-1936 macro hits and misses, beliefs, and evolutions.

Samuelson: As in some other answers to this interview's questions, after a struggle with myself and with my 1932-1936 macro education, I opportunistically began to use The General Theory's main paradigms: the fact that millions of people without jobs envied those like themselves who had jobs, while those in jobs felt sorry for those without them, while all the time being fearful of losing the job they did have. These I took to be established facts and to serve as effective evidence that prices were not being unsticky, in the way that an auction market needs them to be, if full employment clearing were to be assured. Pragmatically and opportunistically, I accepted this as tolerable "micro foundations" for the new 1936 paradigm.

A later writer, such as Leijonhufvud, I knew to have it wrong, when he later argued the merits of Keynes's subtle intuitions and downplayed the various (identical!) mathematical versions of The General Theory. The so-called 1937 Hicks or later Hicks-Hansen IS-LM diagram will do as an example for the debate. Hansen never pretended that it was something original. Actually, one could more legitimately call it the Harrod-Keynes system. In any case, it was isomorphic with an early Reddaway set of equations and similar sets independently exposited by Meade and by Lange. Early on, as a second-year Harvard graduate student, I had translated Keynes's own words into the system that Leijonhufvud chose to belittle as unrepresentative of Keynes's central message.

Just as Darwinism is not a religion in the sense that Marxism usually is, my Keynesianism has always been an evolving development, away from the Neanderthal Model T Keynesianism of liquidity traps and inadequate inclusion of stocks of wealth and stocks of invested goods, and, as needed, included independent variables in the mathematical functions determinative of equilibria and their trends. 
By 1939, Tobin's Harvard Honors thesis had properly added Wealth to the Consumption Function. Modigliani's brilliant 1944 piece improved on 1936 Keynes. Increasingly, we American Keynesians in the Hansen School-Tobin, Metzler, Samuelson, Modigliani, Solow,...,--became impatient with the foot-dragging English—such as Kahn and Robinson-whose lack of wisdoms became manifest in the 1959 Radcliffe Committee Report. The 1931 Kahn that I admired was not the later Kahn, who would assert that the $M V=P Q$ definition contained bogus variables. Indeed, had Friedman explicitly played up, instead of playing down, the key fact that a rash Reagan fiscal deficit could raise $V$ systematically by its inducing higher interest rates, Friedman's would have been less of an eccentric macro model.

I would guess that most MIT Ph.D.'s since 1980 might deem themselves not to be "Keynesians." But they, and modern economists everywhere, do use models like those of Samuelson, Modigliani, Solow, and Tobin. Professor Martin Feldstein, my Harvard neighbor, complained at the 350th Anniversary of Harvard that Keynesians had tried to poison his sophomore mind against saving. Tobin and I on the same panel took this amiss, since both of us since 1955 had been favoring a "neoclassical synthesis," in which full employment with an austere fiscal budget would add to capital formation in preparation for a coming demographic turnaround. I find in Feldstein's macro columns much the same paradigms that my kind of Keynesians use today.

On the other hand, within any "school," schisms do tend to arise. Tobins and Modiglianis never approved of Robert Eisner or Sidney Weintraub as

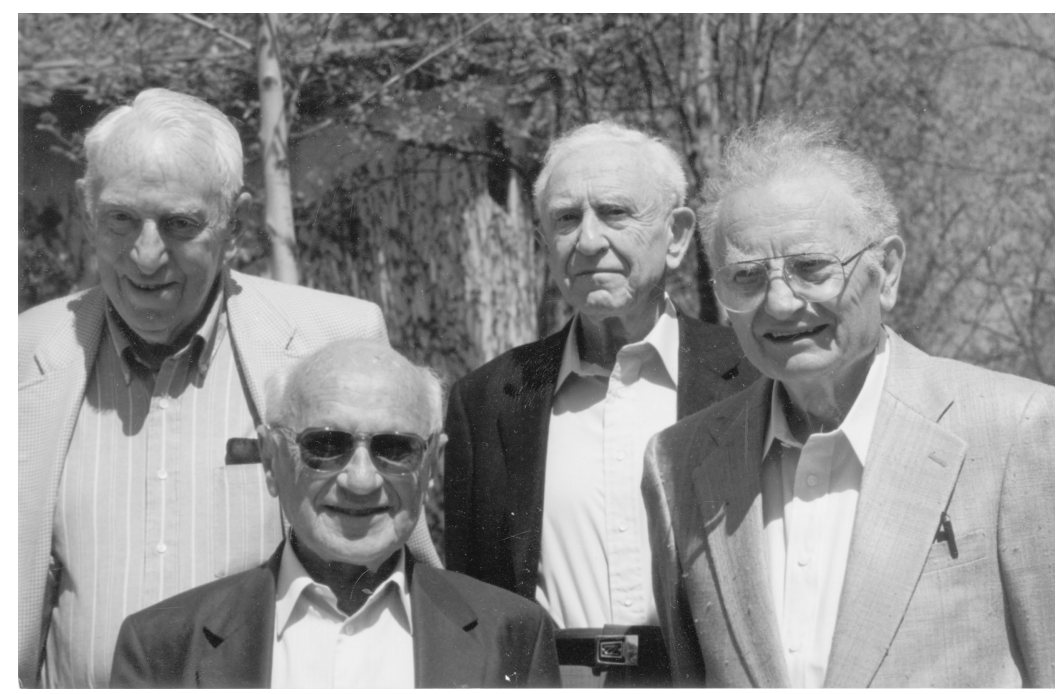

FIGURE 3. Left to right in back: James Tobin and Franco Modiqliani. Left to right in front: Milton Friedman and Paul A. Samuelson. All four are Nobel Laureates in Economics. 
"neo-Keynesians," who denied that lowering of real interest rates might augment capital formation at the expense of current consumption. Nor do I regard as optimal Lerner's Functional Finance that would sanction any sized fiscal deficit so long as it did not generate inflation.

In 1990, I thought it unlikely ever again to encounter in the real world liquidity traps, or that Paradox of Thrift, which so realistically did apply in the Great Depression and which also did help shape our pay-as-you-go nonactuarial funding of our New Deal social security system. In economics what goes around may well come around. During the past 13 years, Japan has tasted a liquidity trap. When 2003 U.S. Fed rates are down to $1 \%$, that's a lot closer to $0 \%$ than it is to a more "normal" real interest rate of $4 \%$ or $5 \%$. Both in micro- and macroeconomics, master economists know they must face up to nonstationary time series and the difficulties these confront us with.

If time permits, I'll discuss later my qualified view about "rational expectations" and about "the New Classicism of Say's law" and neutrality of money in effectuating systemic real-variable changes.

Barnett: What is your take on Friedman's controversial view that his 1950 monetarism was an outgrowth of a forgotten subtle "oral tradition" at Chicago?

Samuelson: Briefly, I was there, knew all the players well, and kept class notes. And beyond Fisher-Marshall $M V=P Q$, there was little else in Cook County macro.

A related and somewhat contradictory allegation by David Laidler proclaimed that Ralph Hawtrey - through Harvard channels of Allyn Young, Lauchlin Currie, and John H. Williams — had an important (long-neglected) influence on Chicago's macro paradigms of that same 1930-1936 period. Again, my informed view is in the negative. A majority of the Big Ten courses did cite Hawtrey, but in no depth.

Before comparing views with me on Friedman's disputed topic (and after having done so), Don Patinkin denied that in his Chicago period of the 1940's any trace of such a specified oral tradition could be found in his class notes (on Mints, Knight, Viner), or could be found in his distinct memory. My Chicago years predated Friedman's autumn 1932 arrival and postdated his departure for Columbia and the government's survey of incomes and expenditures. I took all the macroeconomic courses on offer by Chicago teachers: Mints, Simons, Director, and Douglas. Also in that period, I attended lectures and discussions on the Great Depression, involving Knight, Viner, Yntema, Mints, and Gideonse. Nothing beyond the sophisticated account by Dennis Robertson, in his famous Cambridge Handbook on Money, of the Fisher-Marshall-Pigou $M V=P Q$ paradigm can be found in my class notes and memories.

More importantly, as a star upper-class undergraduate, I talked a lot with the hotshot graduate students - Stigler, Wallis, Bronfenbenner, Hart — and rubbed elbows with Friedman and Homer Jones. Since no whisper reached my ears, and no cogent publications have ever been cited, I believe that this nominated myth should not be elevated to the rank of plausible history of ideas. Taylor Ostrander, then unknown 
to me, did graduate work on the Midway in my time and has kept copious notes. I have asked him and Warren Samuels to comb this important database to confirm or deny these strong contentions of mine.

Having killed off one 1930s' Chicago myth, I do need to report on another too-little-noticed genuine macro oral tradition from the mid-1930's Chicago. It is not at all confirmatory of the Friedman hypothesis, and is indeed $180 \mathrm{E}$ opposed to that in its eclectic doubts about simplistic monetarism. Nor can I cogently connect it with a Young-Hawtrey influence.

You did not have to be a wunderkind to notice in the early 1930's that traditional orthodox notions about Say's law and neutral money were sterile in casting light on contemporary U.S. and global slumps. Intelligently creative scholars such as Simons and Viner had by the mid-1930's learned something from current economic history about inadequacies of the simple $M V=P Q$ paradigm and its " $M$ alone drives $P Q$ " nonsequitur.

Keynes, of course, in shedding the skin of the author of the Treatise, accomplished a virtual revolution by his liquidity preference paradigm, which realistically recognized the systematic variabilities in V. Pigou, when recanting in 1950 from his earlier bitter 1936 review of The General Theory, in effect abandoned what was to become 1950-like monistic Friedmanisms.

Henry Simons, to his credit, already in my pre-1935 undergraduate days, sensed the "liquidity trap" phenomenon. I was impressed by his reasonable dictum: When open-market operations add to the money supply and at the same time subtract equivalently from outstanding quasi-zero-yielding Treasury bills that are strong money substitutes, little increase can be expected as far as spending and employment are concerned. Note that this was some years before the 1938 period, when Treasury bills came to have only a derisory yield (sometimes negative).

Experts, but too few policymakers, were impressed by some famous Viner and Hardy researches for the 1935 Chicago Federal Reserve Bank. These authors interpreted experience of borrowers who could not find lenders as a sign that during (what we subsequently came to call) "liquidity trap times" money is tight rather than loose: Safe Treasury bills are cheap as dirt just because effective tightness of credit chokes off business activity and thereby lowers the marketclearing short interest rate down toward the zero level. Hoarding of money, which entailed slowing down of depression $V$, is then not a psychological aberration; rather, it is a cool and sensible adjustment to a world where potential plenty is aborted by failures in both investment and consumer spending out of expectable incomes (multiplier and accelerator, rigidity of prices and wages, etc.).

Go back now to read Friedman's article for the 1950 International Encyclopedia of the Social Sciences, where as an extremist he plays down (outside of hyperinflation) the effects of $i$ (the interest rate) and fiscal deficits on $V$, to confirm that this Simons-Viner-Hardy Chicago oral tradition is not at all the one he has for a long time claimed to be the early Chicago tradition. (In his defense, I ought to mention that Friedman had left Chicago for Columbia by the time of the Viner-Hardy publications.) The commendable 1932 Chicago proclamation in 
favor of expanded deficit fiscal spending was itself a recognition of the limited potency of $\partial(P Q) / \partial M$. In terms of latter-day logic, a consistent Friedman groupie ought to have refused to sign that 1932 Chicago proclamation. Meantime, in London, Hayek's 1931 Prices and Production had converted the usually sensible Lionel Robbins into the eccentric belief that anything that expanded $M V$ or $P Q$ would only make the Depression worse!

Barnett: You first surfaced as a comer at the University of Chicago. What is your final take on your Midway days?

Samuelson: I was reborn when at age 16 on January 2, 1932, 8:30 a.m., I walked into a Midway lecture hall to be told about Malthusian population. At the zenith of Hutchins's New Chicago Plan, I got a great education in width: physical, biological, and social sciences topped off by humanities.

January 2, 1932, was an auspicious time to begin economic study for two unrelated reasons. The Great Depression was then at its nadir-which attracted good minds into economics and which presented exciting puzzles needing new solutions. The Chicago Midway was a leading center (maybe the leading center) for neoclassical economics, and I found exciting Frank Knight, Henry Simons, Jacob Viner, and Paul Douglas. My very first teacher, Aaron Director (now around 100), I liked as an iconoclastic teacher. He was the only man alive who could (later) speak of "my radical brother-in-law Milton Friedman." Long without Chicago tenure, his bibliography was epsilon. But without any database, he was a primary creator both of the second Chicago School—of Friedman, Stigler, Becker after Knight, Viner, Douglas, Schultz, Nef, and Simons—and present-day antitrust inactivism.

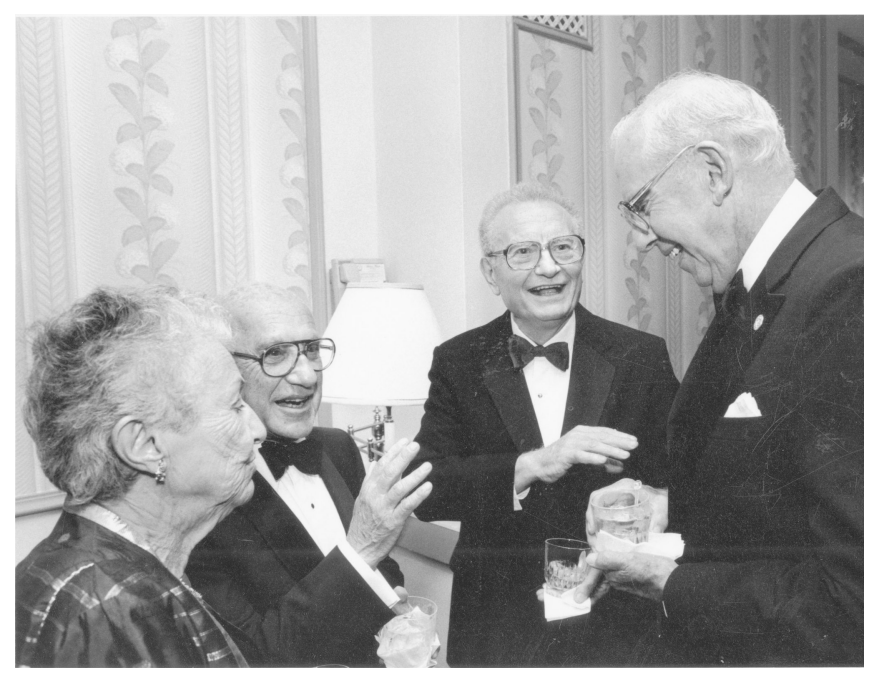

FigURE 4. Left to right, at University of Chicago Centennial, 1991: Rose Director Friedman, Milton Friedman, Paul A. Samuelson, and George Stigler. 
What incredible luck, while still adolescent, to stumble onto the subject that was of perfect interest to me and for which I had special aptitudes! What work I have done has been for me more like play. And always I have been overpaid to do it.

Director's published works are nearly nil, but his was later a major influence on (or against?) antitrust policy, and his stubborn iconoclasm had a significant role in creating the Second Chicago School of Friedman, Stigler, Coase, and Becker. (See the Stigler autobiography.) Since I entered college before graduating from high school, I missed the 1931 autumn quarter during which the Social Science Survey 1 curriculum surveyed economics popularly. As a makeshift, I was put into an oldfashioned, beginners' course that was being phased out. Slichter's Modern Economic Society was Director's assigned text, even though he did not speak well of it. (The following quarter, Lloyd Mints carried on with Richard Ely's best-selling Outline of Economics, with micro theory largely by Allyn Young.) Director's best gift to me was his unorthodox assignment of Gustav Cassel's Theory of Social Economy chapter on "the arithmetic of pricing," as stolen by Cassel from Walras. Few knew in those Model T days about the mathematics of general equilibrium in economics.

But it was Henry Simons, Frank Knight, and Jacob Viner who most influenced my mind. I may have taken more different economics courses at Chicago than anyone before 1935. Certainly, I was overprepared when entering the Harvard Graduate School in 1935. I also carried the baggage of excessive admiration of Frank Knight until time eroded that away.

The best that Knight told us in those days was that in rare depression times, inexplicably Say's law and market clearing somehow didn't obtain temporarily. Most of the time, normalcy would serendipitously return and maybe then we could live happily ever after. Maybe. Meantime the only present choice was between communism and fascism. And for himself, Knight would not choose the latter. Later, understandably, he recovered from that failure of nerve and reneged on his circulated text. Somewhere in my files will be found a copy of his doomsday text.

This explains the second reason why 1932 was a great time for an eager teenager to enter economic study. Our subject had myriads of challenging open problemsproblems that mathematical techniques could throw light on, and also close out. I once described this as being like fishing in a virgin Canadian lake. You threw in your hook and out came theorem after theorem. Viner is a useful example. He was a great economist, and perhaps the most learned one on the 1931 globe. He was also a subtle theorist. With suitable training at McGill and Harvard, Viner could have been a leading mathematical economist. However, Stephen Leacock and Frank Taussig taught him no mathematics at all. This made him fearful of acne-age students like me and our generations who seemed to provide him with painful competition. (To do Viner justice, let me state that the 1930s' graphics of trade theory by Lerner, Leontief, me, and Meade was in its essence already in a 1931 LSE Viner lecture, that the young Lerner would probably have attended.)

I carried a stout staff in the fight to lift the level of mathematical techniques during the second third of the twentieth century. But an evolving science does not wait 
for any one indispensable genius to arrive. Others in plenty would have come along, trained by Hotellings, Evanses, and Frisches to accomplish that overdue task.

Although I've had an acquaintanceship with scores of leading world mathematicians and physicists, I've been surprised at how little help I've been able to garner from presenting orally some unsolved puzzles to them. I should not have been surprised. It is not that a Birkhoff, or Quine, or Ulam, or Levinson, or Kac, or Gleason was incapable of clearing up my open questions. Rather, it is the case that a busy mathematician has no motivation to waste his (or her) time getting intuitively briefed on someone else's models in the idiosyncratic field of mathematical economics. Fortunately, access to the good Harvard and MIT libraries enabled one to ferret out needed book expositions. And it was my good luck that Harvard's E.B. Wilson, only protegé of thermodynamicist Willard Gibbs, provided essential hints that helped in the development of revealed preference and the anticipation of the inequalities techniques in post-1945 economics programming.

Barnett: For some months in 1936 at Harvard, legend reports, you resisted conversion to Keynes's General Theory. Any truth in that?

Samuelson: After 1936 February, when copies of The General Theory arrived in Cambridge, I did struggle with my own initial criticisms of the book; and I suspect my begrudging acceptance of the Keynesian revolution in paradigm was importantly the result of Henry Simon's remark about short-term bonds as a substitute for $M$, when the interest rates are low. I was influenced by that, plus my earlier recognition that prices and price levels are sticky, and therefore neutral money and Say's law lose realism. I knew 100 people without jobs in 1931-1934 and 100 with jobs. The groups would never voluntarily change places: the latter felt very lucky. The former, about equal in ability, felt unlucky. That's not what happens when auction markets equate supply and demand.

Timing is everything. My Society of Fellows 1937-1940 prewar leisure enabled the publication in 1948 of Foundations of Economic Analysis. Groups of youngsters all over the world joined to master its fundamentals. Not until 1983 did I prepare an enlarged edition with terse exposition of post-1947 developments. Why did this better book sell so poorly in comparison with its predecessor? It was because practitioners everywhere had become so much more sophisticated by the end of the century. Schumpeter would say: Monopoly profits are bound to erode away, as knowledge spreads, which is a good thing.

Barnett: So why did you leave Chicago for Harvard?

Samuelson: Given my volition, I would never have left Chicago, but a new Social Science Research Council Fellowship, awarded to the eight most promising economics graduates, bribed me to go to a different university. The effective choice was between Harvard and Columbia. Without exception, my Chicago mentors advised Columbia. By miscalculation, I opted for Harvard, not even knowing that it was about to move out of lean seasons, thanks primarily to the European immigrants Schumpeter, Leontief, Haberler, and also later Alvin Hansen.

Three years later, at Harvard, I did thank providence for my hegira away from the Midway_where I would have missed out on three great twentieth century 
revolutions in economics: the mathematics revolution, the imperfect competition revolution, and the Keynesian effective-demand revolution. I deplore adversary procedures in the healthy evolution of a scientific discipline. Remaining at dogmatically conservative Chicago or accepting its lucrative 1947 professorship would have made me more radical than I wanted to be. For my temperament, serenity would be much more fruitful than the stimulus of polemical debate. I speak only for myself.

Barnett: Franco Modigliani, in his interview in Macroeconomic Dynamics (vol. 4, June 2000), stated that he was discouraged from pursuing an offer early in his career from Harvard University by its Economics Department chair, whom Modigliani characterized as anti-Semitic and xenophobic. When you acquired your Ph.D. from Harvard as an $\mathrm{A}+$ student, having produced one of the most extraordinary dissertations of all times, you were offered a position by MIT, but not by Harvard. Do you believe that the prejudices of the Harvard department chair at that time had a role in Harvard's enormous mistake in that regard? If not, why did they fail to hire you immediately upon receipt of your Ph.D.?

Samuelson: Anti-Semitism was omni-present in pre-World War II academic life, here and abroad. So, of course, my WASP wife and I knew that would be a relevant factor in my career at Harvard. But by 1940, times were changing. Perhaps I had too much of William Tell's hauteur in my personality to ingratiate myself with the circles who gave limited weight to merit in according tenure. When MIT made a good offer, we thought this could test whether there was great enthusiasm for my staying at Harvard. When Harvard's revealed preference consisted of no majority insistence that I stay, we moved three miles down the Charles River. (My Mark Perlman Festschrift piece provides a memoir of an earlier "politically incorrect" age.)

In retrospect, that was the luckiest decision I ever made. In less than a decade, postwar MIT developed into a powerhouse in frontier economics. The Ivy League snared future Rhodes scholars. Our magnet attracted most of the NSF Fellows in economics.

Barnett: Tell us about Harvard in the 1930's.

Samuelson: Hitler (and Lenin) did much for American science. Leontief, Schumpeter, and Haberler brought Harvard to life after a lean period. Alvin Hansen was for me an important influence. Outside of economics, both in the physical sciences and the medical-biological sciences, the U.S. dominates. Actually, toward the end of World War II, when victory was no longer in doubt, I was lent by the Radiation Laboratory to help the Vanevar Bush Secretariat draft Science, the Endless Frontier. Biochemist John Edsall (Harvard), Robert Morison (physiologist at the Rockefeller Foundation), and I did a lot of the draftingof course under the instruction of I.I. Rabi, Edwin Land, Olivier Buckley (head of Bell Lab), and other members of Bush's appointed committee. Against some resistance, what emerged was beyond my fondest hopes: an NSF (inclusive of the Social Sciences), vastly expanded NIH, rather than a nominated plan to give every U.S. county its population quota of dollar subsidies for research. 
Barnett: As you have mentioned, Hitler was responsible for an extraordinary migration of many of Europe's greatest economists to the United States, including Koopmans, Leontief, Schumpeter, Marschak, Haberler, and Kuznets, along with most of the Austrian School of Economics. They in turn helped to attract to this country other major European economists, such as Hurwicz, Debreu, Theil, Bhagwati, Coase, and Fischer. But it is widely believed in much of the world that the United States no longer has the clear political advantage for scholars over Europe that existed at that time, and in fact there is now an increase in the number of American students deciding to study in Canada. Is America in danger of losing its intellectual comparative advantages for economists to other countries?

Samuelson: I do not discern any trend toward foreign out-competition of U.S. science. Sole reason: our predominant real GDP, and the brain drain to us it has induced.

Barnett: Your research from the beginning has shown exceptional influence from the physical sciences, and you mention the work of physical scientists extensively throughout your research, as you did in your famous Foundations. How did you become so heavily influenced by physical scientists? Did you study their work at some point in your education?

Samuelson: I would be rash to ignore analytical sciences outside of the social sciences. But I would be stupid, if out of "physics envy" or snakeoil salesmanship, I would inject into economic theory analytical mathematics that fit only gases and liquids. In my writings, I have criticized wrong analogies to physics by Irving Fisher (whom I admire as a superlative American theorist). Even the genius of von Neumann has not escaped my critical auditings. I have given only qualified approval to Marshall's hope for a more biological and less physical approach to future economics. But that has not aborted my writings in demographical genetics, not all unqualifiably admiring of R.A. Fisher's genetical writings. Maybe someday, future Philip Morowskis or Roy Weintraubs will better fine-tune their nuances.

Barnett: Throughout your career, you have tended to have your "finger in every pie" within the field of economics. But at the present time, it is difficult to think of any economists who are "generalists" in such a total sense. To be influencial in any area of economics requires a degree of specialization that virtually rules out broad influence throughout the field. Is that because of the dramatic expansion of the field and its growth in both breadth and depth, or is it because we don't yet have another young Samuelson on the scene?

Samuelson: If only because of the explosion of total numbers of academic and nonacademic economists, no young Samuelson today could hope to be the kind of generalist that I used to be. Remember I got a young start. I was a fast and voracious reader who turned the pages of all the newly current exchange journals at Harvard's Quarterly Journal of Economics office. The micro tools that worked in general theory also worked in trade theory. With some help from me, post-Keynesian macroeconomics lent itself to complete general equilibrium techniques. Post-Fisher pure finance theory was poised to explode. Since probability 
was a passion with me, the banal statistics taught at Harvard naturally spurred me on to Fisher, Neyman-Pearson, and Wald-Savage further developments.

Having a facile pen helped. Before MIT Chairman Ralph Freeman drafted me to author an elementary text, I wrote for New Republic and other publications. Hansen brought me into Washington New Deal circles.

Barnett: The economics profession widely was in error about the consequences of the Second World War. It is well known that a large percentage of the economics profession, including you in an article in the New Republic, expected an economic collapse at the end of the war. There were a few exceptions, such as Alvin Hansen and Sumner Slichter. Why did so many economists expect the economy to perform badly at the end of the war? In retrospect, it is difficult to understand why that would have been believed, especially in the United States.

Samuelson: Often I've stated how I hate to be wrong. That has aborted many a tempting error, but not all of them. But I hate much more to stay wrong. Early on, I've learned to check back on earlier proclamations. One can learn much from one's own errors and precious little from one's triumphs. By September of 1945, it was becoming obvious that oversaving was not going to cause a deep and lasting postwar recession. So then and there, I cut my losses on that bad earlier estimate. Although Hansen was wise enough to expect a postwar restocking boom, it was his and Keynes's teachings about declining investment opportunities that predisposed my activist contemporaries to fear a post-peace depression. Aside from Hansen and Slichter, Willy Fellner and W.W. Woytinski taped things right: Accumulated saving from the way we financed the war and rationed resources, plus lust for long-delayed comforts and luxuries, were the gasoline that shifted resources from war to full-employment peacetime uses. I knew that argument but did not know what weight to give to it. (Scores of older economists were optimists about 1946 full employment. But if their only support for this view was a dogmatic belief in Say's law, they [Knight is an example] carried little weight with me.)

Mention should be made of another mid-1940's Samuelson error. I judged that the market-clearing real interest rate level would be $3 \%$ or less. That big mistake of course correlated with the earlier unemployment error. I was too stubbornly slow in cutting my losses on that hunch.

Barnett: You were an important Advisor to President John Kennedy. To this day, politicians of both major political parties tend to point to Kennedy's economic policy for support of their agendas. To what degree were those policies influenced by you, and who else played a role in those economic policies?

Samuelson: With great reluctance, I let Senator John F. Kennedy recruit me to his think tank. From nomination date to inaugural day I became his chief economic advisor. Our styles and chemistries clicked. I've never regretted staying out of Washington for two reasons: (1) Research is my true love. (2) The CEA team of Heller, Tobin, and Gordon was the greatest ever. (I did help pick them.) Only when they needed my extra heavy lifting from Cambridge, did I weigh in.

Barnett: How did you become a mathematical economist? Legends proliferate that you began in physics, or mathematics, and then levitated down to economics. 
Samuelson: The truth is that, although I did have aptitude for school math, it was only early in my economic studies that I realized how useful more, and still more, math would be for the puzzles my generation would have to face.

Beulah Shoesmith, spinster, was a famous mathematics teacher at Hyde Park High School near the University of Chicago. A number of scientists came from her workshop. Two of the eight recipients of the 1996 Medal of Science had been her pupils, as were Roy Radner and my brother Bob Summers. I took the many courses offered: advanced algebra, solid geometry, and (boring, surveyorlike) trigonometry. However, in the old-fashioned curriculum, neither calculus nor analytic geometry was considered to be a precollege subject-a terrible mistake. So, after my freshman college year, I hurried to make up for lost time.

Aside from mathematics coursework, I was to a considerable degree selftaught. (When I thought determinants were boring, graduate student George Stigler showed me the big ones Henry Schultz assigned. That wised me up.) Before I knew about Lagrange multipliers, I had worked out the Stackelberg improvements on the Cournot-Nash solution to duopoly. In working out a theory of the circulation of the elite, I discovered matrix multiplication before I knew about matrices-Markov, Frobenius, or Minkowski. I took or audited, at Chicago or Harvard, useful courses from Barnard, Graves, George Birkhoff, Hassler Whitney, Marshall Stone, and especially Edwin Bidwell Wilson. E.B. had been the only protegé at Yale of Willard Gibbs. Since I was Wilson's main protegé, that makes me kind of a grandson to Gibbs.

Fortunately, I was enough ahead of my contemporaries in economics that I had all the time in the world to spend in the library stacks on mathematics. Never did I reach a limit to usefulness of more elaborate mathematics. My economic problems dictated where my math preoccupations should go-not vice versa. Of course, it was Edgeworth, Walras, Pareto, Gibbs, E.B. Wilson, Griffith Evans, Frank Ramsey, Bowley, R.D.G. Allen, Hicks, Frisch, Lotka, Leontief, and von Neumann who were my masters. I'm afraid that I was a captious pupil, often stubbornly critical of my betters. (Example: von Neumann's foundations for cardinal utility in stochastic Laplacian choice begged the issue of the Ramsey-Marschak-SavageDebreu independence axiom by burying that in his zeroth axiom. Worse, he stubbornly ignored all of his critics.)

At Harvard (1935-1940), economists learned little statistics, except in E.B. Wilson's small seminar. Outside Schultz's specialized graduate course, the Chicago economics curriculum had been little better. In the early 1930's, I had to read, on my own, Thurstone's little potboiler to learn about the rudiments of statistics. Only at Columbia was Hotelling teaching 1920-1930 R.A. Fisher. Of course, all this changed rapidly once Wald, Feller, Tukey, and Savage entered the scene.

Barnett: How can we relate your Stolper-Samuelson work, and your later Heckscher-Ohlin-Samuelson research to the present revolts against globalization? Can this trend among some of the world's youth be viewed as opposition by the political left to the implications of your work on trade? 


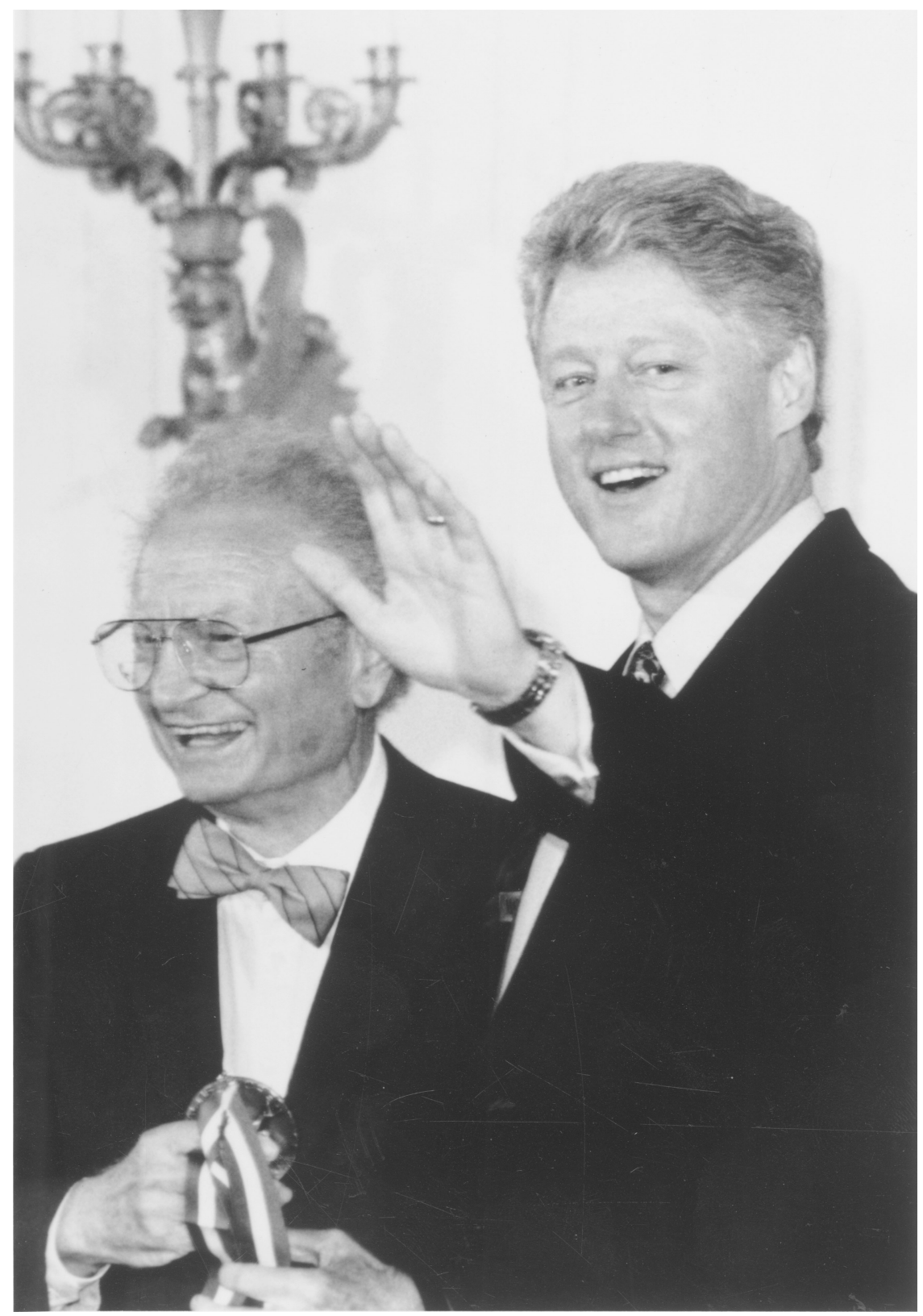

Figure 5. Paul Samuelson with Bill Clinton in White House. 


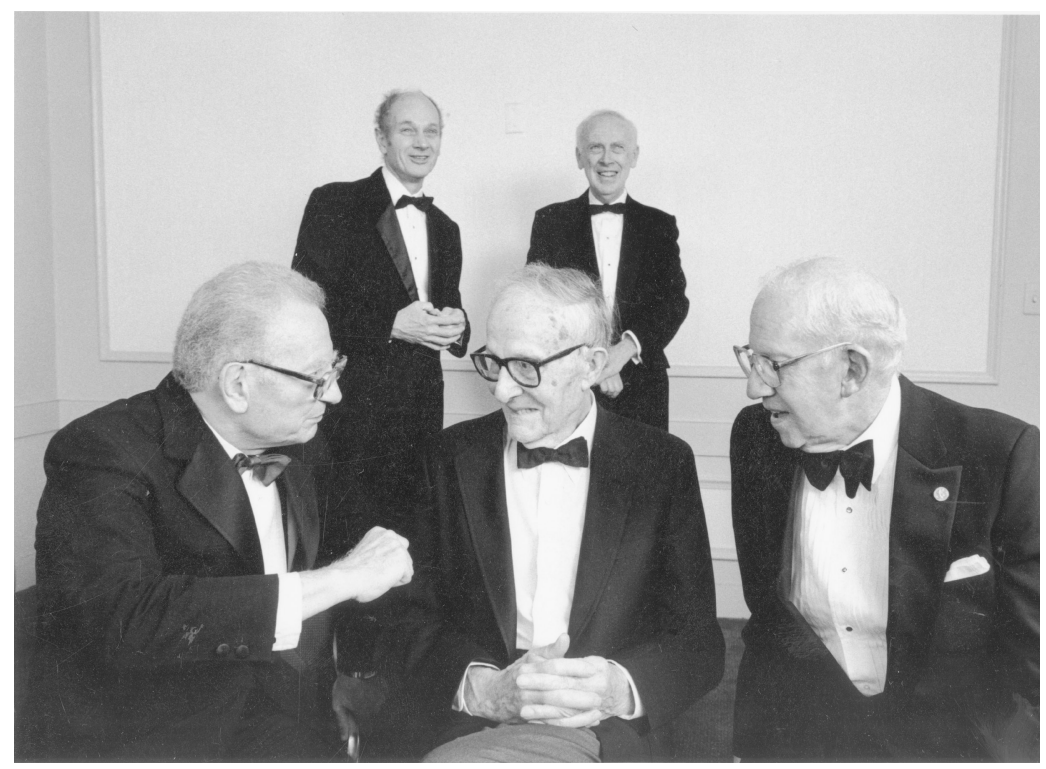

FiguRE 6. Paul Samuelson (front left) with Jerome Friedman (Nobel Prize in Physics), Theodore Schultz (Nobel Prize in Economics), James Watson (Nobel Prize in Biology), and George Stigler (Nobel Prize in Economics) at University of Chicago Centennial, 1991.

Samuelson: Trade is confirmed to be a substitute for massive immigration from poor to rich countries. U.S. labor has lost its old monopoly on American advanced know-how and capital. U.S. total real GDP has net gained (1950-2003) from foreign export-led growth in Pacific Asia and the EU. However, free trade can also systematically affect U.S. wages/GDP share and overall inequality. My little Nobel Lecture ("International Trade for a Rich Country," lecture before the Swedish-American Chamber of Commerce, New York City, May 10, 1972: Stockholm: Federation of Swedish Industries pamphlet, 1972) pointed out that a rich place can lose net when a poor one newly gains comparative advantage in activities in which previously the rich county had enjoyed comparative advantage. Free trade need not help everybody everywhere.

Barnett: Do you have views and reactions to the "rational expectations" approach and real-business-cycle theory? In his dialogue with Robert Shiller in Macroeconomic Dynamics (vol. 3, March 1999), Tobin stated that real-businesscycle theory is "the enemy." In contrast, as is seen in much of the published research appearing in this journal, the use of rational expectations theory (sometimes weakened to include learning) and stochastic dynamic general equilibrium theory is common within the profession among macroeconomists of many political views.

Samuelson: Yes, but a lot of different things are loosely related to the words "rational expectations." One extreme meaning relates to "the new Classical 
doctrine," which alleges in effect that Say's law does obtain even in the short run. I do happen to believe that the U.S. economy (1980-2003) behaves nearer to Say's law's quasi full-employment than did the 1929-1960 U.S. economy, or than does say the modern French and German economies. But this belief of mine does not necessarily require a new Lucas-Sargent methodology. Sufficient for it is two things:

(1) The new 1950-2003 freer global trade has effectively intensified competition with U.S. labor from newly trainable, low-wage Pacific Rim labor-competition strong enough effectively to emasculate the powers of American trade unions (except in public service and some untradeable goods industries). Nowadays every short-term victory by a union only speeds up the day that its industry moves abroad.

(2) There has been a 1980-2003 swing to the right among voters, whose swing away from "altruism" is somewhat proportional to the time elapsed since the Great Depression and since the U.S. government's effective organization for World War II's "good" war. As a result, trade unions no longer benefit from government's help.

A "cowed" labor force runs scared under the newly evolved form of ruthless corporate governance. In contrast to Japan, when a U.S. CEO fires redundant workers quickly, Wall Street bids up the price of the firm's shares.

Another weak form of "rational expectations" I agree with. "Fool me once. Shame on you. Fool me twice. Shame on me." Economic historian Earl Hamilton used to agree with the view that, when New World gold raised 15001900 price levels, nominal wages tended systematically to lag behind. Kessel and Alchian had a point in suspecting that people would at least in part learn to anticipate what has long been going on. I concur to a considerable but limited degree.

Some rational expectationists overshoot, in my judgment, when they exaggerate the "neutrality of money" and the "impotence of government to alter real variables." Friedman's overly simple monetarism à la 1950, was criticized from his left for its gross empirical errors. What must have cut him more personally would come from any Lucas follower who accused Friedman of fallaciously predicting that mismanagement of $M$ in $M V=P Q$ was capable of deep real damage rather than of mere nominal price-level gyration.

Modern statistical methodology, I think, benefits much from Lucas, Sargent, Hansen, Brock, Prescott, Sims, Granger, Engle, and Stock-Watson explorations and innovations. But still much more needs to be analyzed. Strangely, theoryfree vectoral autoregressions do almost as well. Also, variables that pass Granger causality tests can seem to perform as badly in future samples as those that fail Granger tests. And, still the nonstationaryness of economic history confounds actual behavior and necessarily weakens our confidence in inferences from past samples.

This does not lead me to nihilism; but hopefully, only to realism, and, à la Oliver Twist, to urge for more research. 
At many a Federal Reserve meeting with academic consultants, there used to be about one rational expectationist. So unuseful seemed their contributions and judgments that the next meeting entailed a new rational expectationist. And each year's mail would bring to my desk a few dozen yellow-jacket manuscripts from the National Bureau, purporting to test some version of rational expectationism. Many were nominated for testing; few passed with flying colors the proposed tests. I continue to live in both hope and doubt.

In some quarters, it is a popular belief that macroeconomics is less scientific than micro and less to be admired. That is not my view. I think macroeconomics is very challenging, and at this stage of the game it calls for wiser judgments. A lively science thrives on challenges, and that is why I transfer a good deal of my time and energy from micro to macro research. Probably as a syndicated columnist, I have published at monthly intervals a couple of thousand different journalistic articles. Maybe more. My aim is not to be interesting but rather, as best as I can, not to be wrong. When my conjecture is still a conjecture, I try to mark it as such. My notion of a fruitful economic science would be that it can help us explain and understand the course of actual economic history. A scholar who seriously addresses commentary on contemporary monthly and yearly events is, in this view, practicing the study of history-history in its most contemporary time phasing.

\section{NOTES}

1. Perhaps those rare exceptions might include game theoretic and topological models and maybe the recent literatures on complex unstable nonlinear dynamics, sunspots, and incomplete markets. But I would not be surprised, if he were to correct those speculations as misperceptions, if I were to ask.

2. The current URL of that Web site is http://cepa.newschool.edu/het/home.htm.

SELECTED SCIENTIFIC PUBLICATIONS OF PAUL A. SAMUELSON

BOOKS

1947

Foundations of Economic Analysis. Cambridge, MA: Harvard University Press.

1948

Economics: An Introductory Analysis. New York: McGraw-Hill.

1958

Linear Programming and Economic Analysis, with R. Dorfman \& R.M. Solow. New York: McGrawHill. 


\section{6-2004}

The Collected Scientific Papers of Paul A. Samuelson, Cambridge, MA: MIT Press, five volumes, with volumes 6 and 7 in process, containing over 550 reprinted published papers; vols. 1 and 2, J.E. Stiglitz (ed.), 1966; vol. 3, R.C. Merton (ed.), 1972; vol. 4, H. Nagatai \& K. Crowley (eds.), 1977; vol. 5, K. Crowley (ed.), 1986; vols. 6 and 7, J.M. Murray (ed.), in process.

\section{ARTICLES}

\section{7}

A note on measurement of utility. Review of Economic Studies 4, 155-161.

Some aspects of the pure theory of capital. Quarterly Journal of Economics 51, 469-496.

\section{8}

A note on the pure theory of consumer's behaviour. Economica 5 (Feb.), 61-71.

Numerical representation of ordered classifications and the concept of utility. Review of Economic Studies 6, 65-70.

\section{9}

Interaction between the multiplier analysis and the principle of acceleration. Review of Economic Studies 21, 75-78.

\section{1}

The stability of equilibrium: Comparative statics and dynamics. Econometrica 9, 97-120.

\section{2}

Constancy of the marginal utility of income. In Lange et al. (eds.), Studies in Mathematical Economics and Econometrics in Memory of Henry Schultz, pp. 75-91. Chicago: University of Chicago Press.

\section{4}

The relation between Hicksian stability and true dynamic stability. Econometrica 12, 256-257.

\section{7}

Some implications of linearity. Econometrica 15, 88-90.

\section{8}

Consumption theory in terms of revealed preference. Economica 15, 243-253.

International trade and the equalisation of factor prices. Economic Journal 58, 163-184. 
International factor-price equalisation once again. Economic Journal 59, 181-197.

1950

Evaluation of real national income. Oxford Economic Papers 2, 1-29.

Probability and the attempts to measure utility. Economic Review 1, 167-173.

The problem of integrability in utility theory. Economica 17, 355-385.

\section{1}

Abstract of a theorem concerning substitutability in open Leontief models. In T.C. Koopmans (ed.), Activity Analysis of Production and Allocation, Ch. 7, pp. 142-146. New York: Wiley.

\section{2}

Economic theory and mathematics: An appraisal. American Economic Review 42, 56-66.

Probability, utility, and the independence axiom. Econometrica 20, 670-678.

Spatial price equilibrium and linear programming. American Economic Review 152, 283-303.

\section{3}

Balanced growth under constant returns to scale. with R.M. Solow. Econometrica 21, 412-424.

Consumption theorems in terms of overcompensation rather than indifference comparisons. Economica 20, 1-9.

Prices of factors and goods in general equilibrium. Review of Economic Studies 21, 1020.

\section{4}

Diagrammatic exposition of a theory of public expenditure. Review of Economics and Statistics 37, 350-356.

The pure theory of public expenditure. Review of Economics and Statistics 36, 387-389.

\section{6}

A complete capital model involving heterogeneous capital goods, with R.M. Solow. Quarterly Journal of Economics 70, 537-562.

Social indifference curves. Quarterly Journal of Economics 70, 1-22.

\section{7}

Wages and interest: A modern dissection of Marxian economic models. American Economic Review $47,884-912$.

\section{8}

An exact consumption-loan model of interest with or without the social contrivance of money. Journal of Political Economy 66, 467-482.

Aspects of public expenditure theory. Review of Economics and Statistics 40, 335-338. 


\section{9}

Reply to Lerner. Journal of Political Economy 67, 518-522.

\section{0}

Analytical aspects of anti-inflation policy, with R.M. Solow. American Economic Review 50, 177-194. Efficient paths of capital accumulation in terms of the calculus of variations. in K.J. Arrow, S. Karlin, \& P. Suppes (eds.), pp. 77-88. Mathematical Models in Social Science, Stanford: Stanford University Press.

\section{2}

Parable and realism in capital theory: The surrogate production function. Review of Economic Studies 29, 193-206.

\section{5}

A catenary turnpike theorem involving consumption and the golden rule. American Economic Review $55,486-496$.

A theory of induced innovation along Kennedy-Weizsacker Lines. Review of Economics and Statistics 47, 343-356.

Proof that properly anticipated prices fluctuate randomly. Industrial Management Review 6, 41-49. Rational theory of warrant pricing. Industrial Management Review 6, 13-39.

Using full duality to show that simultaneously additive direct and indirect utilities imply unitary price elasticity of demand. Econometrica 33, 781-796.

\section{6}

A summing up. Quarterly Journal of Economics 80, 658-683.

The non-switching theorem is false, with D. Levhari. Quarterly Journal of Economics 80, 518559.

The Pasinetti paradox in neoclassical and more general models, with F. Modigliani. Review of Economic Studies 33, 269-301.

\section{7}

General proof that diversification pays. Journal of Finance and Quantitative Analysis 2, 1-13.

\section{8}

What classical and neoclassical monetary theory really was. Canadian Journal of Economics 1, 1-15. Two generalizations of the elasticity of substitution. In J.N. Wolfe (ed.), Value, Capital, and Growth: Essays in Honour of Sir John Hicks, pp. 467-480, Edinburgh: Edinburgh University Press.

\section{9}

Lifetime portfolio selection by dynamic stochastic programming. Review of Economics and Statistics 51, 239-246. 
The fundamental approximation theorem of portfolio analysis in terms of means, variances and higher moments. Review of Economic Studies 37, 537-542.

\section{1}

Understanding the Marxian notion of exploitation: A summary of the so-called transformation problem between Marxian values and competitive prices. Journal of Economic Literature 9, 399-431.

\section{2}

Maximum principles in analytical economics. American Economic Review 62, 249-262.

Unification theorem for the two basic dualities of homothetic demand theory. Proceedings of the National Academy of Sciences 69, 2673-2647.

\section{4}

Complementarity: An essay on the 40th anniversary of the Hicks-Allen revolution in demand theory. Journal of Economic Literature 12, 1255-1289.

Invariant economic index numbers and canonical duality: Survey and synthesis, with S. Swamy. American Economic Review 64, 566-593.

Marx as a mathematical economist. In G. Horwich \& P. Samuelson (eds.), Trade, Stability and Macroeconomics, P. II, pp. 269-307. New York: Academic Press.

\section{8}

The canonical classical model of political economy. Journal of Economic Literature 16, 1415-1434.

\section{4}

Unattainability of integrability and definiteness conditions in the general case of demand for money and goods, with Ryuzo Sato. American Economic Review 74, 588-604. 